\section{Laktosetoleranz-Test mit Ethanol}

R. Tauber und F. H. Perschel

Institut für Laboratoriumsmedizin, Klinische Chemie und Pathobiochemie, Charité - Universitätsmedizin Berlin, Campus Virchow-Klinikum, Berlin, Deutschland

Englischer Begriff Oral lactose tolerance test with ethanol

Definition Funktionstest zum Nachweis einer Laktosemalabsorption, der auf der Messung der Blutglukosekonzentration nach oraler Gabe von Laktose beruht und bei dem gegenüber dem einfachen Laktosetoleranz-Test die Umwandlung von $\triangleright$ Galaktose zu $\triangleright$ Glukose in der Leber durch zusätzliche Gabe von Ethanol gehemmt wird.

Durchführung 15 Minuten vor Laktosegabe werden dem nüchternen Patienten $300 \mathrm{mg}$ Ethanol pro $\mathrm{kg} \mathrm{KG}$ per os gegeben. Die weitere Durchführung entspricht der des normalen $>$ Laktosetoleranz-Test, wobei jedoch die Blutgalak- tosekonzentration anstelle der Blutglukosekonzentration bestimmt wird.

Funktion - Pathophysiologie $>$ Laktosetoleranz-Test.

Untersuchungsmaterial-Entnahmebedingungen Abhängig von der Bestimmungsmethode: Kapillarblut, Venenblut, Plasma.

Analytik Enzymatische Messung der Konzentration von Galaktose.

Referenzbereich - Erwachsene Galaktosekonzentration in Vollblut oder Serum $>5 \mathrm{mg} / \mathrm{dL}(0,3 \mathrm{mmol} / \mathrm{L})$

\section{Literatur}

Lembcke B (2012) Laktosetoleranz-Test. In: Thomas L (Hrsg) Labor und Diagnose. Indikation und Bewertung von Laborbefunden für die medizinische Diagnostik, 8. Aufl. TH-Books, Frankfurt am Main, S 770-773 